\title{
Cross-Host Protection of Marine Bacteria Against Macroalgal Disease
}

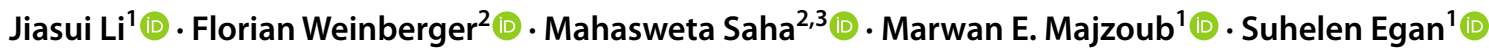

Received: 13 September 2021 / Accepted: 24 October 2021

(c) The Author(s), under exclusive licence to Springer Science+Business Media, LLC, part of Springer Nature 2021

\begin{abstract}
Despite an increasing awareness of disease impacts on both cultivated and native seaweed populations, the development of marine probiotics has been limited and predominately focused on farmed animals. Bleaching (loss of thallus pigmentation) is one of the most prevalent diseases observed in marine macroalgae. Endemic probiotic bacteria have been characterized to prevent bleaching disease in red macroalgae Agarophyton vermiculophyllum and Delisea pulchra; however, the extent to which probiotic strains provide cross-protection to non-endemic hosts and the influence of native microbiota remain unknown. Using A. vermiculophyllum as a model, we demonstrate that co-inoculation with the pathogen Pseudoalteromonas arctica G-MAN6 and D. pulchra probiotic strain Phaeobacter sp. BS52 or Pseudoalteromonas sp. PB2-1 reduced the disease risks compared to the pathogen only treatment. Moreover, non-endemic probiotics outperformed the endemic probiotic strain Ralstonia sp. G-NY6 in the presence of the host natural microbiota. This study highlights how the native microbiota can impact the effectiveness of marine probiotics and illustrates the potential of harnessing probiotics that can function across different hosts to mitigate the impact of emerging marine diseases.
\end{abstract}

Keywords Agarophyton vermiculophyllum $\cdot$ Bleaching mitigation $\cdot$ Gracilaria vermiculophylla $\cdot$ Probiotics $\cdot$ Seaweed disease $\cdot$ Delisea pulchra

Infectious diseases have been reported as one of the main factors threatening marine macroalgae (seaweeds) in wild populations [1-3] and farmed species [4, 5]. However, current disease management strategies, involving specific cultivation practices or chemical treatments [6,7], are often highly labor-intensive and impractical for the application to wild seaweed populations. The use of probiotics for disease control in industrial and natural systems is gaining interest [8-12], yet in the marine environment disease protective bacteria have predominately been characterized for aquaculture animals $[13,14]$ with few attempts made to discover macroalgal probiotics [15-17]. To date, research has focused

Suhelen Egan

s.egan@unsw.edu.au

1 Centre for Marine Science and Innovation, School of Biological, Earth and Environmental Sciences, Faculty of Science, The University of New South Wales, Kensington, NSW 2052, Australia

2 Marine Ecology Division, GEOMAR Helmholtz Centre for Ocean Research Kiel, Düsternbrooker Weg 20, 24105 Kiel, Germany

3 Marine Ecology and Biodiversity, Plymouth Marine Laboratory, Prospect Place, Plymouth PL1 3DH, UK either on the isolation of endemic probiotic bacteria from the target hosts and their environment or on the use of wellcharacterized human/animal dietary probiotics such as Lactobacillus spp. or Bacillus spp. [14]. While such approaches contribute to the development of new probiotics, animal probiotics may not be well adapted to the marine macroalgal environment. Moreover, little is understood about the extent to which the function of a marine probiotic strain is host specific (but see $[18,19]$ ). Addressing these knowledge gaps serves as the cornerstone of developing common probiotics as a generalized solution to emerging aquatic diseases.

Bleaching is one of the most common diseases observed in macroalgae [2, 20-22] including Agarophyton vermiculophyllum in the Baltic Sea [16] and wild Delisea pulchra populations in Australia [23]. A common feature of bleaching is that disease appears to be a result of opportunistic pathogens exploiting the stressed hosts. We have recently identified a range of bacteria that can antagonize pathogens that cause D. pulchra bleaching disease, including two strains (Pseudoalteromonas sp. PB2-1 and Phaeobacter sp. BS52) that can reduce the pathogen-induced bleaching in vivo [15]. Similarly, endemic bacterial strains have been shown to reduce the risk of disease in A. vermiculophyllum 
in the presence of pathogens [16]. However, previous studies were conducted on A. vermiculophyllum pre-treated with antibiotics; thus, the extent to which probiotics are effective in reducing the risk of disease in the presence of the macroalga's undisturbed natural microbiota remains unknown. Here we test the hypothesis that protective bacteria of $D$. pulchra are also effective in controlling pathogen-induced disease in A. vermiculophyllum and that disease protection is influenced by the host's surface microbiota.

Healthy A. vermiculophyllum [24] (synonym: Gracilaria vermiculophylla (Ohmi) Papenfuss) samples without any apparent thallus discoloration were collected from the sandy shores at Nordstrand $\left(53^{\circ} 29^{\prime} 10.25^{\prime \prime} \mathrm{N}, 8^{\circ} 38^{\prime} 35.33^{\prime \prime} \mathrm{E}\right)$, from December 2018 to March 2019, and transported to the GEOMAR Helmholtz Centre for Ocean Research labs (Kiel, Germany) within $2 \mathrm{~h}$. Macroalgal maintenance and in vivo bleaching disease assays were conducted as previously described [16] (see also Supplementary Information).

We first determined if the non-endemic candidate probiotics (Pseudoalteromonas sp. PB2-1; Phaeobacter sp. BS23, BS34, and BS52; Photobacterium sp. BS55; and Vibrio sp. BL95) had a detrimental impact on A. vermiculophyllum health and compared these to both the representative pathogen Pseudoalteromonas arctica G-MAN6 and the endemic protective strain Ralstonia sp. G-NY6 [16] (Table 1). Each strain was inoculated separately in bleaching assays of $A$. vermiculophyllum with a disturbed (pre-treated with antibiotics vancomycin and cefotaxime each at a final concentration of $0.1 \mathrm{mg} \cdot \mathrm{ml}^{-1}$ for 2 days following the procedures outlined in [16]) or natural microbiota (i.e., no antibiotic pretreatment). The number of healthy and bleached tips from each fragment was counted after 5 days using a binocular microscope (Fig. S1). The relative risk (RR) for each treatment compared to the seawater control (SW) was calculated using the formula below [25] and the effect of each treatment tested using a Generalized Linear Mixed-effect Model with a $p$ value of $<0.05$ considered significant (see also Supplementary Information).

Absolute risk of tip bleaching in Treatment $X(\%)$

$=\frac{\text { Number of bleached tips in Treatment } X}{\text { Number of tested tips in Treatment } X} \times 100$

Absolute risk of tip bleaching in Control (\%)

$=\frac{\text { Number of bleached tips in Control }}{\text { Number of tested tips in Control }} \times 100$

A $R R=1$ means the risk of tip bleaching is identical in the treatment and control. An RR $<1$ or $>1$ means the treatment reduces or increases the risk compared to the control.

The addition of non-endemic bacteria did not alter the disease risk of $A$. vermiculophyllum compared to the control samples (Fig. 1; Table S1). In contrast, adding $P$. arctica G-MAN6 to $A$. vermiculophyllum resulted in a significant increase in bleaching compared to the control, in samples with both a disturbed and natural microbiota $\left(\mathrm{RR}_{\text {disturbed microbiota }}=2.36\right.$, $\mathrm{RR}_{\text {natural microbiota }}=2.25$; Fig. 1, Table S1), thereby confirming its role as a pathogen. Interestingly, inoculation of the endemic probiotic strain Ralstonia sp. G-NY6 lowered the disease risk to approximately one-third compared to the SW control in A. vermiculophyllum with disturbed microbiota, but doubled the disease risk in the presence of the natural microbiota $\left(\mathrm{RR}_{\text {disturbed microbiota }}=0.36, \mathrm{RR}_{\text {natural microbiota }}=2.11\right.$; Fig. 1, Table S1). These results suggest that Ralstonia sp. G-NY6 could compromise host health through interacting with other microbiota members and highlight the importance of testing probiotics in the presence of a natural microbiota.

Table 1 Bacteria tested in Agarophyton vermiculophyllum bleaching disease assays

\begin{tabular}{|c|c|c|c|c|}
\hline Bacterial ID & Taxonomy & Original habitat & Ecological role & Reference/Provider \\
\hline G-MAN6 & Pseudoalteromonas arctica & Surface of A. vermiculophyllum & A. vermiculophyllum pathogen & {$[16]$} \\
\hline G-NY6 & Ralstonia sp. & Surface of A. vermiculophyllum & $\begin{array}{l}\text { A. vermiculophyllum bleaching } \\
\text { protective strain }\end{array}$ & {$[16]$} \\
\hline PB2-1 & Pseudoalteromonas sp. & Surface of D. pulchra & $\begin{array}{l}\text { D. pulchra bleaching protective } \\
\text { strain }\end{array}$ & {$[15,26]$} \\
\hline BS23 & Phaeobacter sp. & Surface of D. pulchra & $\begin{array}{l}\text { D. pulchra pathogen-antagonis- } \\
\text { tic strain }\end{array}$ & $\begin{array}{l}\text { Sharon Longford, UNSW } \\
\text { Sydney; [15] }\end{array}$ \\
\hline BS34 & Phaeobacter sp. & Surface of Ulva australis & $\begin{array}{l}\text { D. pulchra pathogen-antagonis- } \\
\text { tic strain }\end{array}$ & {$[15,27]$} \\
\hline BS52 & Phaeobacter sp. & Surface of D. pulchra & $\begin{array}{l}\text { D. pulchra bleaching protective } \\
\text { strain }\end{array}$ & {$[15,27]$} \\
\hline BS55 & Photobacterium sp. & Surface of D. pulchra & $\begin{array}{l}\text { D. pulchra pathogen-antagonis- } \\
\text { tic strain }\end{array}$ & {$[15,27]$} \\
\hline BL95 & Vibrio sp. & Surface of D. pulchra & $\begin{array}{l}\text { D. pulchra pathogen-antagonis- } \\
\text { tic strain }\end{array}$ & $\begin{array}{l}\text { Vipra Kumar, UNSW Sydney; } \\
\text { [15] }\end{array}$ \\
\hline
\end{tabular}




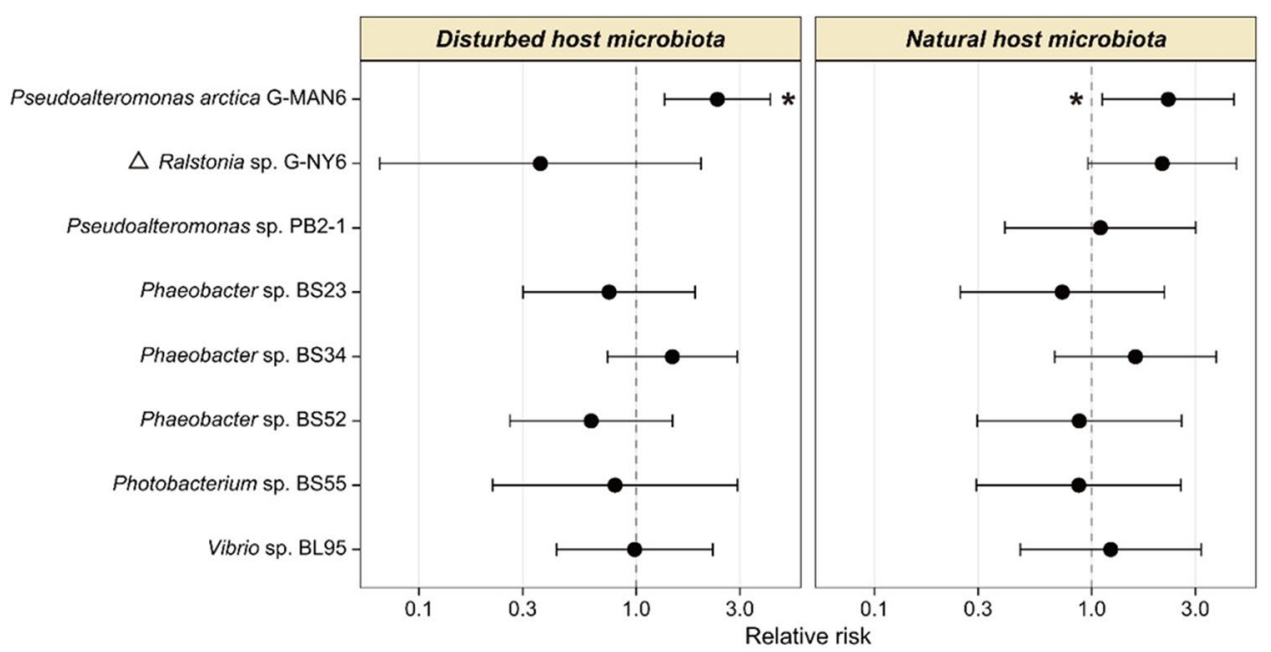

Fig. 1 Effect of single bacterial strain inoculums on the risk of bleaching disease in Agarophyton vermiculophyllum with a disturbed or a natural microbiota. The $x$-axis shows the relative risk (RR, calculated for three independent experiments with six biological replicates each) and $95 \%$ confidence intervals (CIs). Note that no diseased tips were observed in Pseudoalteromonas sp. PB2-1 treatment in A. vermiculophyllum with disturbed microbiota; thus, the CIs could not be estimated. The vertical dashed line indicates $R R=1.0$ (i.e., the risk of test strain treatment equals to the corresponding control). The $y$-axis

After showing that the non-endemic candidate probiotics did not themselves result in an increased risk of tip bleaching (Fig. 1; Table S1), we further tested whether any of them could reduce pathogen-induced bleaching in A. vermiculophyllum. Each of the candidate probiotics was co-inoculated with the pathogen $P$. arctica G-MAN6 in A. vermiculophyllum with a disturbed or natural microbiota. In A. vermiculophyllum with a disturbed microbiota, coinoculations with Phaeobacter sp. BS23, BS34, and BS52 or Ralstonia sp. G-NY6 resulted in a significant decrease in the disease risks compared to the pathogen only treatment $\left(\mathrm{RR}_{\mathrm{BS} 23+\mathrm{G}-\mathrm{MAN} 6}=0.20, \mathrm{RR}_{\mathrm{BS} 34+\mathrm{G}-\mathrm{MAN} 6}=0.15\right.$, $\mathrm{RR}_{\mathrm{BS} 52+\mathrm{G}-\mathrm{MAN} 6}=0.18, \mathrm{RR}_{\mathrm{G}-\mathrm{NY} 6}+\mathrm{G}-\mathrm{MAN} 6=0.32$ ), while there was no statistical support for a change in these disease risks compared to the SW controls (Fig. 2; Table S2). However, when the microbiota was present, co-inoculation of $P$. arctica G-MAN6 and either Phaeobacter sp. BS23, Phaeobacter sp. BS52, or Pseudoalteromonas sp. PB2-1 resulted in a significant decrease in disease risks compared to the pathogen alone $\left(\mathrm{RR}_{\mathrm{BS} 23}+\mathrm{G}-\mathrm{MAN} 6=0.29, \mathrm{RR}_{\mathrm{BS} 52+\mathrm{G}-\mathrm{MAN} 6}=0.19\right.$, $\mathrm{RR}_{\mathrm{PB} 2-1+\mathrm{G}-\mathrm{MAN6}}=0.24$; post hoc tests on Poisson GLMM: $\left.p_{\text {adjusted }}<0.05\right)$. Moreover, Phaeobacter sp. BS23 and BS52 strains outperformed Ralstonia sp. G-NY6 in disease protective effects in A. vermiculophyllum (Fig. 2).

Collectively these results show that $D$. pulchra bleachingprotective strains Phaeobacter sp. BS52 and Pseudoalteromonas sp. PB2-1 [15] could also alleviate the pathogen-induced bleaching in A. vermiculophyllum. Bacteria shows the taxonomic affiliation and identification number (ID) of test bacteria. Multiple comparisons (emmeans function in $\mathrm{R}$ emmeans package) on a two-way Poisson GLMM ( $D f=83)$ were performed to examine the differences between treatments and SW control (* indicates a significant difference), and between host microbiota status ( $\triangle$ indicates a significant difference). The confidence levels and $p$ values were adjusted using a mvt method. An adjusted $p$ value of $<0.05$ was considered significant

belonging to the genera Phaeobacter and Pseudoalteromonas have also been reported as probiotics in a variety of marine systems, including corals [28], shellfish [11, 29, 30], and fish larvae [31-33]. Together with these studies, our current work supports the idea that Phaeobacter and Pseudoalteromonas strains show promise as general marine probiotics.

Factors that contribute to the success of Pseudoalteromonas spp. as a probiotic could be due to direct or indirect inhibition of pathogens, e.g., the production of antibiotics [34, 35] or bacterial quorum sensing inhibitors [36]. It should be noted, however, that Pseudoalteromonas sp. PB2-1 provided significant protection to A. vermiculophyllum in the presence of the host natural microbiota, but only displayed moderate protection on A. vermiculophyllum with a disturbed microbiota. These observations suggest that the direct antibiotic activities of Pseudoalteromonas sp. PB2-1 may not be sufficient to protect $A$. vermiculophyllum against disease. Rather PB2-1 may have an indirect mode of action for disease protection, such as mitigating pathogen-induced dysbiosis (e.g., see $[15,37,38]$ ), or acting in synergy with other members of the microbiota to afford protection to the host.

Host microbiota have previously been hypothesized to play a key role in health maintenance through inhibiting detrimental colonizers including pathogens [39]. However, our results suggest that different probiotic strains can perform differently depending on the host microbiota. For example, 


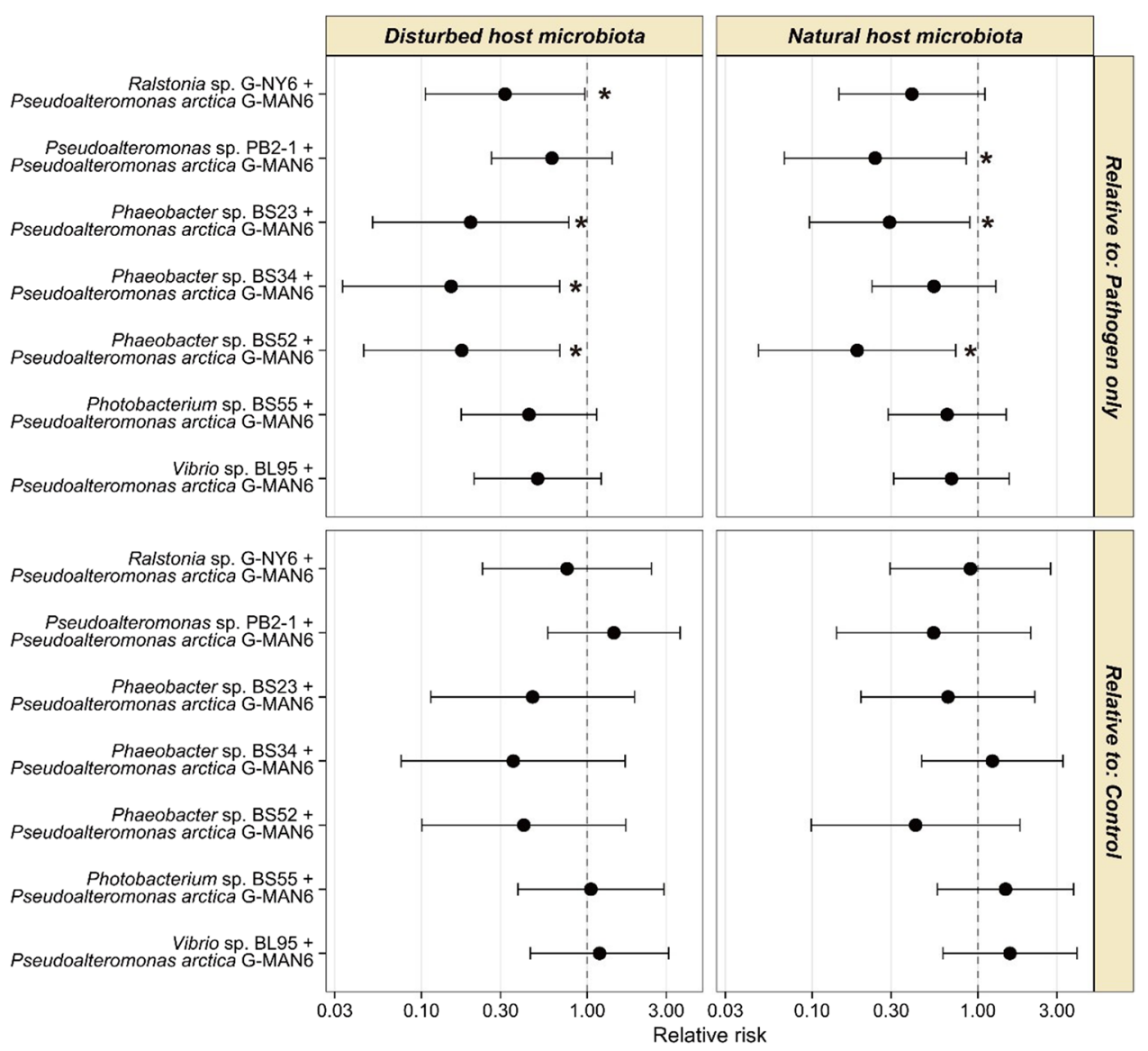

Fig. 2 Effect of co-inoculation of candidate protective bacteria and the pathogen Pseudoalteromonas arctica G-MAN6 on the risk of bleaching disease in Agarophyton vermiculophyllum with a disturbed or a natural microbiota. The pathogen only treatment and SW control are used as references to calculate the relative risk (RR) of different co-inoculation treatments (results are shown in top and bottom panels, respectively). The $x$-axis shows the RR (calculated for three independent experiments with six biological replicates each) and 95\% confidence intervals (CIs). The vertical dashed line indicates $\mathrm{RR}=1.0$ (i.e., the risk of co-inoculation treatment equals to the cor- responding pathogen only treatment or SW control). The $y$-axis shows the taxonomic affiliation and identification number (ID) of inoculated bacteria. Multiple comparisons (emmeans function in $\mathrm{R}$ emmeans package) on a two-way Poisson GLMM $(D f=83)$ were performed to examine the differences between treatments and pathogen only or SW control (* indicates a significant difference), and between host microbiota status ( $\triangle$ indicates a significant difference). The confidence levels and $p$ values were adjusted using a mvt method. An adjusted $p$ value of $<0.05$ was considered significant

counts similar to the inoculum levels) in non-axenic cultures [40]. The mechanisms through which tripartite interactions among the host microbiota, pathogens, and probiotics affect the final disease outcomes on the host will be an important area for future research and our findings highlight the necessity of testing probiotics in near natural systems.

In summary, we have shown that Phaeobacter sp. BS52 and Pseudoalteromonas sp. PB2-1 can protect the two phylogenetically and geographically distinctive red seaweeds D. pulchra and A. vermiculophyllum from their pathogeninduced bleaching disease, even in the presence of a native microbiome. Understanding these ecological interactions will help pave the way for the use of common probiotics to facilitate marine host conservation and sustainable aquaculture. 
Supplementary Information The online version contains supplementary material available at https://doi.org/10.1007/s00248-021-01909-2.

Acknowledgements The authors are grateful to Guido Bonthond for helping with field sampling. The authors thank Eve Slavich and Stats Central at UNSW for providing statistical advice. Jiasui Li acknowledges the receipt of the China Scholarship Council scholarship and the UNSW Tuition Fee Scholarship, and the receipt of the DAAD (German Academic Exchange Service) Short-Term Research Grant, which supported her visiting in GEOMAR Helmholtz Centre for Ocean Research Kiel, Germany.

Author Contribution JL, FW, MS, and SE contributed to the study conception and design. FW and JL prepared the experimental materials. JL and MS performed the experiments. JL analyzed the data. JL and SE wrote the first draft of the manuscript. All authors commented on previous versions of the manuscript. All authors read and approved the final manuscript.

Funding Jiasui Li was awarded a DAAD (German Academic Exchange Service) Short-Term Research Grant (ID: 57381332) to undertake the project.

Data availability Raw data of alga infection assays are deposited at https://doi.org/10.6084/m9.figshare.16576244.

Code Availability Code for analyses is available at: https://doi.org/10. 6084/m9.figshare.16576244.

\section{Declarations}

Ethics Approval Not applicable.

Consent to Participate Not applicable.

Consent for Publication Not applicable.

Conflict of Interest The authors declare no competing interests.

\section{References}

1. Ferrari J, Goncalves P, Campbell AH, Sudatti DB, Wood GV, Thomas T, Pereira RC, Steinberg PD, Marzinelli EM (2021) Molecular analysis of a fungal disease in the habitat-forming brown macroalga Phyllospora comosa (Fucales) along a latitudinal gradient. J Phycol. https://doi.org/10.1111/jpy.13180

2. Egan S, Fernandes ND, Kumar V, Gardiner M, Thomas T (2014) Bacterial pathogens, virulence mechanism and host defence in marine macroalgae. Environ Microbiol 16:925-938. https://doi. org/10.1111/1462-2920.12288

3. Campbell AH, Verges A, Steinberg PD (2014) Demographic consequences of disease in a habitat-forming seaweed and impacts on interactions between natural enemies. Ecology 95:142-152. https://doi.org/10.1890/13-0213.1

4. Faisan JP, Luhan MRJ, Sibonga RC, Mateo JP, Ferriols VMEN, Brakel J, Ward GM, Ross S, Bass D, Stentiford GD (2021) Preliminary survey of pests and diseases of eucheumatoid seaweed farms in the Philippines. J Appl Phycol 33:2391-2405. https://doi. org/10.1007/s10811-021-02481-5
5. Ward GM, Faisan JP Jr, Cottier-Cook EJ, Gachon C, Hurtado AQ, Lim PE, Matoju I, Msuya FE, Bass D, Brodie J (2020) A review of reported seaweed diseases and pests in aquaculture in Asia. J World Aquacult Soc 51:815-828. https://doi.org/10.1111/jwas. 12649

6. Kambey CSB, Campbell I, Cottier-Cook EJ, Nor ARM, Kassim A, Sade A, Lim PE (2021) Seaweed aquaculture: a preliminary assessment of biosecurity measures for controlling the ice-ice syndrome and pest outbreaks of a Kappaphycus farm. J Appl Phycol. https://doi.org/10.1007/s10811-021-02530-z

7. García-Poza S, Leandro A, Cotas C, Cotas J, Marques JC, Pereira L, Gonçalves AMM (2020) The evolution road of seaweed aquaculture: cultivation technologies and the industry 4.0. Int J Environ Res Public Health 17:6528. https://doi.org/10.3390/ijerph1718 6528

8. Peixoto RS, Sweet M, Villela HDM, Cardoso P, Thomas T, Voolstra CR, Høj L, Bourne DG (2021) Coral probiotics: premise, promise, prospects. Annu Rev Anim Biosci 9:265-288. https:// doi.org/10.1146/annurev-animal-090120-115444

9. Cunningham M, Azcarate-Peril MA, Barnard A, Benoit V, Grimaldi R, Guyonnet D, Holscher HD, Hunter K, Manurung S, Obis D, Petrova MI, Steinert RE, Swanson KS, van Sinderen D, Vulevic J, Gibson GR (2021) Shaping the future of probiotics and prebiotics. Trends Microbiol 29:667-685. https://doi.org/10.1016/j.tim. 2021.01.003

10. Vishwakarma K, Kumar N, Shandilya C, Mohapatra S, Bhayana S, Varma A (2020) Revisiting plant-microbe interactions and microbial consortia application for enhancing sustainable agriculture: a review. Front Microbiol 11:560406. https://doi.org/10.3389/fmicb. 2020.560406

11. Ring $\varnothing$ E (2020) Probiotics in shellfish aquaculture. Aquaculture and Fisheries 5:1-27. https://doi.org/10.1016/j.aaf.2019.12.001

12. Pérez-Sánchez T, Mora-Sánchez B, Balcázar JL (2018) Biological approaches for disease control in aquaculture: advantages, limitations and challenges. Trends Microbiol 26:896-903. https://doi. org/10.1016/j.tim.2018.05.002

13. El-Saadony MT, Alagawany M, Patra AK, Kar I, Tiwari R, Dawood MAO, Dhama K, Abdel-Latif HMR (2021) The functionality of probiotics in aquaculture: an overview. Fish Shellfish Immunol 117:36-52. https://doi.org/10.1016/j.fsi.2021.07.007

14. Hoseinifar SH, Sun Y-Z, Wang A, Zhou Z (2018) Probiotics as means of diseases control in aquaculture, a review of current knowledge and future perspectives. Front Microbiol 9https://doi. org/10.3389/fmicb.2018.02429

15. Li J, Majzoub ME, Marzinelli EM, Dai Z, Thomas T, Egan S (2021) Bacterial controlled mitigation of dysbiosis in a seaweed disease. ISME J. https://doi.org/10.1038/s41396-021-01070-1

16. Saha M, Weinberger F (2019) Microbial "gardening” by a seaweed holobiont: surface metabolites attract protective and deter pathogenic epibacterial settlement. J Ecol 107:2255-2265. https://doi. org/10.1111/1365-2745.13193

17. Weinberger F, Hoppe H-G, Friedlander M (1997) Bacterial induction and inhibition of a fast necrotic response in Gracilaria conferta (Rhodophyta). J Appl Phycol 9:277-285. https://doi.org/10. 1023/A:1007990712925

18. Duan Y, Zhang Y, Dong H, Wang Y, Zheng X, Zhang J (2017) Effect of dietary Clostridium butyricum on growth, intestine health status and resistance to ammonia stress in Pacific white shrimp Litopenaeus vannamei. Fish Shellfish Immunol 65:25-33. https://doi.org/10.1016/j.fsi.2017.03.048

19. Duan Y, Zhang Y, Dong H, Wang Y, Zhang J (2017) Effect of the dietary probiotic Clostridium butyricum on growth, intestine antioxidant capacity and resistance to high temperature stress in kuruma shrimp Marsupenaeus japonicus. J Therm Biol 66:93100. https://doi.org/10.1016/j.jtherbio.2017.04.004 
20. Arasamuthu A, Edward J (2018) Occurrence of ice-ice disease in seaweed Kappaphycus alvarezii at Gulf of Mannar and Palk Bay, Southeastern India. Indian J Geo-Mar Sci 47:1208-1216

21. Largo DB, Fukami K, Nishijima T (1995) Occasional pathogenic bacteria promoting ice-ice disease in the carrageenan-producing red algae Kappaphycusalvarezii and Eucheumadenticulatum (Solieriaceae, Gigartinales, Rhodophyta). Journal Appl Phycol 7:545-554. https://doi.org/10.1007/BF00003941

22. Weinberger F, Friedlander M, Gunkel W (1994) A bacterial facultative parasite of Gracilaria conferta. Dis Aquat Organ 18:135141. https://doi.org/10.3354/dao018135

23. Case RJ, Longford SR, Campbell AH, Low A, Tujula N, Steinberg PD, Kjelleberg S (2011) Temperature induced bacterial virulence and bleaching disease in a chemically defended marine macroalga. Environ Microbiol 13:529-537. https://doi.org/10.1111/j.14622920.2010.02356.x

24. Gurgel CFD, Norris JN, Schmidt WE, Le HN, Fredericq S (2018) Systematics of the Gracilariales (Rhodophyta) including new subfamilies, tribes, subgenera, and two new genera, Agarophyton gen. nov. and Crassa gen. nov. Phytotaxa 374:1-23. https://doi.org/10. 11646/phytotaxa.374.1.1

25. Andrade C (2015) Understanding relative risk, odds ratio, and related terms: as simple as it can get. J Clin Psychiatry 76:857861. https://doi.org/10.4088/JCP.15f10150

26. Kumar V, Zozaya-Valdes E, Kjelleberg S, Thomas T, Egan S (2016) Multiple opportunistic pathogens can cause a bleaching disease in the red seaweed Delisea pulchra. Environ Microbiol 18:3962-3975. https://doi.org/10.1111/1462-2920.13403

27. Penesyan A, Marshall-Jones Z, Holmstrom C, Kjelleberg S, Egan S (2009) Antimicrobial activity observed among cultured marine epiphytic bacteria reflects their potential as a source of new drugs. FEMS Microbiol Ecol 69:113-124. https://doi.org/10.1111/j. 1574-6941.2009.00688.x

28. Rosado PM, Leite DCA, Duarte GAS, Chaloub RM, Jospin G, da Nunes Rocha U, Saraiva JP, Dini-Andreote F, Eisen JA, Bourne DG, Peixoto RS (2019) Marine probiotics: increasing coral resistance to bleaching through microbiome manipulation. ISME J 13:921-936. https://doi.org/10.1038/s41396-018-0323-6

29. Offret C, Rochard V, Laguerre H, Mounier J, Huchette S, Brillet B, Le Chevalier P, Fleury Y (2019) Protective efficacy of a Pseudoalteromonas strain in European abalone, Haliotis tuberculata, infected with Vibrio harveyi ORM4. Probiotics Antimicrob Proteins 11:239-247. https://doi.org/10.1007/s12602-018-9389-8

30. Sorieul L, Wabete N, Ansquer D, Mailliez J-R, Pallud M, Zhang C, Lindivat M, Boulo V, Pham D (2018) Survival improvement conferred by the Pseudoalteromonas sp. NC201 probiotic in Litopenaeus stylirostris exposed to Vibrio nigripulchritudo infection and salinity stress. Aquaculture 495:888-898. https://doi.org/10. 1016/j.aquaculture.2018.06.058
31. Makridis P, Kokou F, Bournakas C, Papandroulakis N, Sarropoulou E (2021) Isolation of Phaeobacter sp. from larvae of Atlantic bonito (Sarda sarda) in a mesocosmos unit, and its use for the rearing of European seabass larvae (Dicentrarchus labrax L.). Microorganisms 9:128. https://doi.org/10.3390/microorganisms9 010128

32. Sonnenschein EC, Jimenez G, Castex M, Gram L (2020) The Roseobacter-group bacterium Phaeobacter as safe probiotic solution for aquaculture. Appl Environ Microbiol 87:e02581-e2620. https://doi.org/10.1128/AEM.02581-20

33. Rasmussen BB, Kalatzis PG, Middelboe M, Gram L (2019) Combining probiotic Phaeobacter inhibens DSM17395 and broadhost-range vibriophage KVP40 against fish pathogenic vibrios. Aquaculture 513:734415. https://doi.org/10.1016/j.aquaculture. 2019.734415

34. Richards GP, Watson MA, Needleman DS, Uknalis J, Boyd EF, Fay JP (2017) Mechanisms for Pseudoalteromonas piscicidainduced killing of vibrios and other bacterial pathogens. Appl Environ Microbiol 83:e00175-e117. https://doi.org/10.1128/ AEM.00175-17

35. Yu M, Wang J, Tang K, Shi X, Wang S, Zhu W-M, Zhang X-H (2012) Purification and characterization of antibacterial compounds of Pseudoalteromonas flavipulchra JG1. Microbiology 158:835-842. https://doi.org/10.1099/mic.0.055970-0

36. Liu N, Yu M, Zhao Y, Cheng J, An K, Zhang X-H (2017) PfmA, a novel quorum-quenching $N$-acylhomoserine lactone acylase from Pseudoalteromonas flavipulchra. Microbiology 163:1389-1398. https://doi.org/10.1099/mic.0.000535

37. Zhao J, Ling Y, Zhang R, Ke C, Hong G (2018) Effects of dietary supplementation of probiotics on growth, immune responses, and gut microbiome of the abalone Haliotis diversicolor. Aquaculture 493:289-295. https://doi.org/10.1016/j.aquaculture.2018.05.011

38. Buffie CG, Bucci V, Stein RR, McKenney PT, Ling L, Gobourne A, No D, Liu H, Kinnebrew M, Viale A, Littmann E, van den Brink MRM, Jenq RR, Taur Y, Sander C, Cross JR, Toussaint NC, Xavier JB, Pamer EG (2015) Precision microbiome reconstitution restores bile acid mediated resistance to Clostridium difficile. Nature 517:205-208. https://doi.org/10.1038/nature13828

39. Egan S, Harder T, Burke C, Steinberg P, Kjelleberg S, Thomas T (2013) The seaweed holobiont: understanding seaweed-bacteria interactions. FEMS Microbiol Rev 37:462-476. https://doi.org/ 10.1111/1574-6976.12011

40. Grotkjær T, Bentzon-Tilia M, D’Alvise P, Dierckens K, Bossier P, Gram L (2016) Phaeobacter inhibens as probiotic bacteria in non-axenic Artemia and algae cultures. Aquaculture 462:64-69. https://doi.org/10.1016/j.aquaculture.2016.05.001 